\title{
Jordan Peterson and the (F)law of 'Scientific Inquiry': A Critical Evaluation of Peterson's Use of Science and Philosophy in His Conquest Against Social Justice
}

\section{David Guignion}

https://doi.org/10.22151/politikon.41.1

David Guignion is a Doctoral Student in Media Studies at The University of Western Ontario, Ontario, Canada. His Master's thesis explored the intersection of Jean Baudrillard's work with posthumanism. E-mail: dguignio@uwo.ca

\begin{abstract}
This article explores Jordan Peterson's political project in response to Canada's legislation of Bill C-16, a bill seeking to add gender expression to the list of grounds for discrimination under the criminal code. Peterson opposes Bill C-16 because it presents, for him, an ideological mode of speech and thought regulation. For Peterson, this bill is the result of the decline of scientific validity and the rise of a postmodernism motivated by the desire to undermine Western civilization. Therefore, this article argues that Peterson's challenge to postmodern thought as an anti-scientific doctrine is perplexing given the general lack of consensus between his views and those of the greater scientific community. The article presents different theoretical frameworks attesting to the reality of gender non-conforming identities as well as to the consequences of denying these identities, and argues that rather than challenging oppressive systems of governance, Peterson's project actually mirrors them.
\end{abstract}

\section{Keywords}

Friedrich Nietzsche; Gender; Hannah Arendt; Jean Baudrillard; Jordan Peterson; Judith Butler; Totalitarianism; Trans-identities 


\section{Introduction}

If all enigmas are resolved, the stars go out. If everything secret is returned to the visible [...], if all illusion is returned to transparence then heaven become indifferent to the earth.

—Jean Baudrillard (2008a: 79)

What is the purpose, and, worse still, what is the origin of all science? What? Is scientific method perhaps no more than fear of and flight from pessimism? A subtle defence against truth? Or, to put it in moral terms, is it something like cowardice and insincerity? To put it immorally, is it a form of cunning? O, Socrates, Socrates, was that perhaps your secret? O, mysterious ironist, was this perhaps your - irony?

—Friedrich Nietzsche (2007: 4)

On September $27^{\text {th }}$ 2016, Jordan Peterson, a psychology professor at the University of Toronto, released a YouTube video of himself speaking out against Bill C-16, a law proposed by the Canadian government that would add "gender identity and gender expression to the list of prohibited grounds of discrimination in the Canadian Human Rights Act and [to] the list of characteristics of identifiable groups protected from hate propaganda in the Criminal Code" (Parliament of Canada, 2016). For Peterson, and many of his right-wing followers, Bill C-16 represents a shift towards an impending totalitarian regime that seeks to restrict freedom of speech and deny scientific reason. As he stated in an address to a group of students at the University of Toronto, "I have studied totalitarianism for four decades and I know how it starts" (Peterson, 2016a). According to Peterson, anyone that agrees with and promotes Bill C-16 must necessarily oppose "logic," "dialogue," and “Western civilization" (Peterson, 2017a). Peterson's video, along with his vocal refusal to adopt gender-neutral pronouns, marked the beginning of Peterson's rise to fame.

This article discusses Jordan Peterson's crusade against Bill C-16 in order to challenge his utilization of scientific discourse to promote his ideological position on contemporary social issues. His arguments can be difficult to follow as they are riddled with aporias and contradictions that make a coherent analysis nearly impossible. For example, he has been vocal about his fear of a looming totalitarian regime while simultaneously calling for the complete abolishment of the Ontario Human Rights Commission that serves to "promote and enforce human rights, to engage in relationships that embody the principles of dignity and respect, and to create a culture of human rights compliance and accountability" (Ontario Human Rights Commission). Despite this, this article categorizes his overall project into three broad conceptual domains: his arguments about postmodernism, his "scientific" discourse, and gender identity. The article traverses each of these domains sequentially, giving credence to his arguments by constructing them in a coherent manner to allow for a steady theoretical terrain from which to mount this polemic. This strategy is employed to give a face to an 
otherwise faceless argument and to make this dialogue possible. In relation to these three domains, this article presents counter-arguments and evidence that destabilize the facile deployment of a scientific rationality by Peterson and his allies and therefore calls into question many of his central claims.

This paper moves through each of these domains methodically, beginning with his juxtaposition of postmodernism with neo-Marxism, all the while claiming to be a faithful reader to Friedrich Nietzsche. This section demonstrates not only that postmodernism and neo-Marxism are two incommensurable terms, but that Nietzsche's work has heavily influenced what Peterson labels postmodernism. Moreover, this section attempts to destabilize his problematic association of postmodern philosophy with totalitarianism. To do this, this paper invokes Hannah Arendt's The Origins of Totalitarianism (1994), a seminal text on the rise of totalitarianism in the $20^{\text {th }}$ century. This use of Arendt's theorization of the rise of totalitarianism in the $20^{\text {th }}$ century serves as a plea for Peterson and his followers to recognize the parallels between those movements in the $20^{\text {th }}$ century and much of the rhetoric that dominates our social Zeitgeist today. Moving from this domain, the second section presents divergent scientific data that attests to the reality of trans* identities. This section presents a number of scientific studies on the increasing risk experienced by trans* people today and the measures that should be taken to alleviate these risks. This section will serve the purpose of demonstrating the fragility of so-called scientific rationality and will call into question his axiomatic faith in science as universal and ahistorical. The third and final section presents the voices of those marginalized by Peterson and his allies in an effort to highlight the present efforts by marginalized folks to resist the erasure committed by Peterson. This section places these marginalized voices, and their theoretical approaches alongside the work of Jean Baudrillard and his consideration of simulation and singularity.

\section{The Incommensurability of Marxism and Postmodernism}

Peterson predicates a great deal of his political work on the flawed assumption that postmodernism is a threatening political doctrine that derives from Marxism. He often characterizes social activism as being propagated by "bloody neo-Marxists" who wish to promote postmodernism, a "pernicious and philosophically primitive and nihilistic doctrine" (Peterson, 2016c). Peterson argues that the rise of postmodernism constitutes the first step in replacing basic scientific tenets with "radical social constructionism" (Peterson, 2016c), a theoretical framework that would, according to him, allow the Left to replace a so-called objective Truth rooted in biology and genetics with a socially constructed human identity. He adds, in one of his many public lectures, that postmodernism is a "well developed and pervasive, pernicious, nihilistic, intellectually attractive doctrine" that now "dominates the humanities and...social sciences" (Peterson, 2017a). 
Furthermore, Peterson suggests that European Marxist thought, defined by Richard D. Wolff and Stephen Cullenberg as a theory that distinguishes "the production and distribution of surplus labor from...matters of property and power" (Wolff and Cullenberg, 1986: 128), has been re-appropriated by contemporary postmodernists who have transposed the hegemonic Marxist relationship of "poor against rich" onto the broader postmodernist domain of the "oppressed against the oppressor" (Peterson, 2017a). With this argument, he therefore suggests that postmodernism is merely a clever Marxist "sleight of hand" (Peterson, 2017a) seeking, like its Marxist predecessor, to undermine the West.

Clare Hemmings problematizes this approach to postmodernism and Marxism by emphasizing some of the most significant differences between the two theoretical frameworks. She writes that postmodernism's "attention to complexity of meaning and interpretation distracted us from [the] more substantive concerns with inequality, experience, political economy, and justice" (Hemmings, 2011: 97) that Marxism attends to. Hemmings extends this analysis by suggesting that, without a Marxist — or other tangible approach to critical theory_ " we remain powerless to alter the pernicious power relations our poststructuralist tactics can cleverly identify but spectacularly fail to transform" (Hemmings, 2011: 97-8). Hemmings's point stresses the lack of consistency between Marxist and poststructuralist theories, demonstrating their fundamental incongruency in the domain of political action, with the former emphasizing a radical transformation of capitalism into a socialist system, and the latter belonging to the domain of theory interested in the immaterial conditions of signification.

Jean Baudrillard, referred to by some as the "high priest of postmodernism" (1993a, 21), is one such figure that greatly disturbs Peterson's conflation of Marxist and postmodern theories. In The Mirror of Production, Baudrillard vehemently challenges Marxism, asking: "are we, quite simply, within a mode of production at all, and have we ever been in one?' (Baudrillard, 1973: 124). Baudrillard extends this question by turning his critical gaze back on Marxism, suggesting that Marxism is predicated on the fundamentally Eurocentric tenets of "productivism, scientism, and historicism" (Baudrillard, 1973: 73), and that it homogenizes earlier societies under the "light of the present structure of the capitalist economy" therefore silencing specific sociohistorical contexts, projecting onto them "the spectral light of political economy" (Beaudrillard, 1973: 66). This book marked a fundamental turning point in Baudrillard's work as he grew wary of the possibility that Marxism could actually provide the blueprints for an effective mode of societal change. Postmodernism, as demonstrated with Baudrillard's work, does not share an indubitable affinity with Marxism, but actually condemns it. 
Baudrillard is not the only thinker indicative of postmodernism to be critical of Marxism however. Michel Foucault, who Peterson argues attempted to "resurrect Marxism" (Peterson, 2017b), is another such figure of the so-called postmodern tradition that has been highly critical of Marxism. In The Order of Things, he systematically avoids discussing Marxism in terms of economic theory in favour many other liberal approaches to economics indicative of the work of Adam Smith and François Quesnay. Foucault does this because, as he makes abundantly clear, he believes that "Marxism exists in nineteenth century thought like a fish in water: that is, it is unable to breathe anywhere else" (Foucault, 2005: 285). This sentiment resonates in harmony with the overarching themes of his work because he refuses to acknowledge that societal ills, or power, can be reduced to a single structural locus. Thus, Foucault is highly sceptical of the possibility of a meaningful societal revolution because, without a comprehensive evaluation of the plethora of institutions that govern our daily lives, we risk perpetuating the same oppressive schema.

Peterson's definition of postmodernism, however, seems to exclude this type of postmodernist critique of Marxism. For him, the contemporary postmodern movement is simply a "new skin that the old Marxism now inhabits" made up of nihilistic yet dominating "neo-Marxists" guided by a desire to dismantle the "structure of Western civilization” (2017d). Although Peterson's fears of nihilism, or the disavowal of moral or ethical principles, may appear sound, his contradictory position on postmodernism as both fundamentally nihilistic and actively dominating delegitimate one of his central concerns. Additionally, the thinkers that Peterson cites as representatives of the postmodern movement-Michel Foucault and Jacques Derrida-were greatly indebted to the Western philosophical and literary canons with some commentators even labeling them "NeoKantians” (Meštrović, 2013: 154). Peterson's reduction of these thinkers to philosophical aberrations, detached from Western Civilization, illuminates his own obliviousness to said canon.

\section{Peterson, Arendt, and Totalitarianism}

In Peterson's Maps of Meaning he tries to grapple with and understand the historical instantiations of state mandated fascist and totalitarianism in the $20^{\text {th }}$ century. One of the central questions he asks is, "How was it possible for people to act the way the Nazis had during World War II?" (Peterson, 1999: xii). What is particularly striking is that Peterson makes no significant use of Hannah Arendt, the thinker of fascism and totalitarianism par excellence. He does mention her briefly however, suggesting that her seminal text, The Banality of Evil would have been more appropriately titled “'The Evil of Banality"' (Peterson, 1999: 369). The absence of Arendt's work in Peterson's exploration of these themes is suspicious, and signals that his understanding of totalitarianism is missing integral philosophical insight. This is particularly true of the lineage he traces between nihilism and the development of totalitarianism. 
Even if we were to overlook the contradictory nature of Peterson's position on nihilism and political praxis, and were to engage with his scientific terms immanently, his linking of nihilism with totalitarianism remains problematic. As Hannah Arendt argues in The Origins of Totalitarianism, "indifference to public affairs [and] neutrality on political issues, are in themselves no sufficient cause for the rise of totalitarian movements" (Arendt, 1994: 313). According to Arendt, it is the "strong man" rather than the indifferent public that has historically lead to the rise of totalitarian regimes. As she explains, competitive and hostile "attitudes are very useful for those forms of dictatorship in which a 'strong man' takes upon himself the troublesome responsibility for the conduct of public affairs" (Arendt, 1994: 313) and hardly conform to traditional or typical definitions of nihilism.

Though Arendt's observations regarding the "strong man" and totalitarianism more broadly are based on her experiences during the Jewish Holocaust, many of her theories seem to run parallel to Peterson's claims regarding scientific rationality and human nature. This is not to say that Peterson directly emulates the fascist movements of the $20^{\text {th }}$ century, as that comparison would be erroneous and misguided. Rather, Arendt's description of the "strong man" as founded upon "the belief in a kind of human 'nature' which would be subject to the same laws of growth as that of the individual" (Arendt, 1994: 298) shares a strong affinity with Peterson's persistent reliance on essentialist positions, as illustrated in statements about "essential female [and] masculine patholog[ies]" (Peterson, 2017e). Arendt elaborates on these "essentialist beliefs" as irrelevant since "Western philosophy and religion" has been defining and redefining it "for more than three thousand years" (Arendt, 1994: 298). Furthermore, such assumptions do very little to protect the rights of those who we consider human but still deprive of "expression within and acting upon a common world" (Arendt, 1994: 302). These sorts of oppressive mechanisms through which human nature is established and used to justify the removal of legal and/or political rights were used quite successfully by the Nazi regime during the Second World War. As Arendt explains, "the Nazis started their extermination of Jews by first depriving them of all legal status" (Arendt, 1994: 296) and then depriving them of their homes (Arendt, 1994: 293), therefore leaving them without "territory and (...) government of their own” (Arendt, 1994: 19). By expelling the Jewish people from any "community willing and able to guarantee any rights whatsoever," the Nazis were therefore able to expel them from humanity itself (Arendt, 1994: 297).

The oppressive mechanisms adopted by the Nazis are not only observable in the context of the Second World War, however, and can in fact be observed today. As Mary Ellen Donnan reveals in The Shattered Mosaic: How Canadian Social Structures Cause Homelessness (2016), "the national data indicates that although only about $10 \%$ of the general youth population identify as lesbian, gay, bisexual, transgendered, transsexual, or two-spirited, people who identify in those ways make up 25 
to $40 \%$ of the youth homeless population" (Donnan, 2016: 60). Interestingly, such statistics are ignored by Peterson, who prefers instead to claim that Bill C-16 only poses a threat to freedom of speech. This attitude is exemplified in an address given at the University of Toronto in which Peterson stated, in response to a trans* person's concerns: "I don't believe that using your pronouns will do you any good in the long run" (Peterson, 2016b). Peterson's silence on issues of poverty and homelessness in the trans* community in Canada, combined with his aggressive stance against laws that seek to recognize trans* people and protect them from discrimination, mirror the tactics used by totalitarian regimes (such as the Nazi regime) to oppress marginalized communities.

\section{Nietzsche and Postmodernism}

As previously discussed, Peterson's construction of contemporary social activism as a nihilistic and dangerous threat to Western values and scientific discourse born out of the postmodern movement is dependent on the axiom that the "fundamental assumptions of Western civilization are valid" (Peterson, 2017c). Though Peterson centers most of his core arguments around this "fundamental assumption," his appreciation for Friedrich Nietzsche, a theorist described by the Stanford Encyclopedia of Philosophy as a "precursor for postmodernism in his genealogical analyses of fundamental concepts, especially what he takes to be the core concept of Western metaphysics" (Alesworth, 2015), remains unshaken.

In The Birth of Tragedy, Nietzsche argues that the notions of "Truth" that run through the course of history are founded, not on their objectivity, but in their continual self-proclamation of objectivity. For Nietzsche, the shift from language to science placed the scientific method at the forefront of Western civilization, making everything quantifiable under the scientific gaze. As he explains, "it is language which works on building the edifice of concepts; later it is science" (Nietzsche, 2007: 150). Nietzsche expands on this idea, writing: "what I understand by the spirit of science is the belief, which first came to light in the person of Socrates, that the depths of nature can be fathomed and that knowledge can heal all ills" (Nietzsche, 2007: 82). According to Nietzsche, this belief in the ultimate infallibility of science, or "Socrates' tendency to murder art" (Nietzsche, 2007: 82), is destructive, especially when left unacknowledged. To Nietzsche, science is "truly capable of confining the individual within the smallest circle of solvable tasks" (Nietzsche, 2007: 85). As he explains, "science, spurred on by its powerful delusion, is hurrying unstoppably to its limits, where the optimism hidden in the essence of logic will founder and break up" (Nietzsche, 2007: 75).

There is no thinker that would stand as opposed to Peterson as Nietzsche, whom Peterson repeatedly cites and applauds in his 12 Rules for Life: An Antidote to Chaos. Peterson has remarked of Nietzsche that he is as an "absolute intellectual tour de force of staggering magnitude" (Peterson, 2017f) and that he has influenced "every philosopher of the modern age [in] one way or another" (Peterson, 
2017g). 12 Rules for Life, proclaiming the necessity for people (young men) to adopt an ascetic lifestyle in the form of a mutated Christian conservatism, stands diametrically opposed to Nietzsche's central claim in The Genealogy of Morality that the ascetic ideal is not something to strive for, but is rather the consequence of a life attempting to inject artificial meaning into its veins in a poor attempt at inoculation from degeneration (Nietzsche, 2017: 89). In this capacity, Peterson resembles the “ascetic priest" that Nietzsche castigates (Nietzsche, 2017: 89). The task of intellectuals should not be to inject arbitrary rules and regulations into people, but rather to foster "perspectival seeing" that welcomes "more eyes, various eyes we are able to use" to sketch a more complete understanding of our "objectivity" (Nietzsche, 2017: 89).

According to Peterson, the Western scientific discourse he holds so dear is not merely threatened by a general postmodern movement made up of nameless "neo-Marxist" social justice warriors, but rather, may be seen in specific actions taken by the members of this movement. These specific threats are especially apparent in relation to challenges made to the male/female binary. As Peterson explains, legislation (such as the proposed Bill C-16) that seeks to expand gender categories is "patently absurd" (Peterson, 2016c) and undeniably driven by "ideologues" that want to push "made up words" (Peterson, 2017h). Peterson is not so much concerned with the so-called 'absurdity' of these challenges as he is with the threat they pose to his belief system. For Peterson, "rational discourse," "objectivity" and "scientific inquiry" (Peterson, 2017i) must necessarily be silenced for non-binary gender identities to exist and, because these concepts are paramount to Eurocentrism and the "success" of the West, Peterson dismisses any questions about their validity as intrinsically unfounded. With this dismissal, Peterson therefore eliminates the potential for any meaningful dialogue that may not align itself with his fixed opinions.

Peterson's project is an attempt then to move away from the Nietzschean notion of "perspectival seeing" toward the domains of ahistorical, and acontextual seeing. This narrowing of possibility operates to maintain the authority of those who choose what is considered worth seeing, and through what means, pushing society toward the sovereign and dictatorial rule.

\section{The 'Science' vs. Peterson}

Though Peterson's line of argumentation seems to suggest a science/postmodernism opposition, a considerable number of scientific journals have published articles addressing the growing stigmatization and discrimination trans and genderqueer people experience regularly. Such articles, though they conform to the same scientific rationale utilized by Peterson, shed light on the great deal of contradictions, oppositions and divergent beliefs in this supposedly "objective" field of study. These studies correspond to the domain of research that aligns with the Aristotelian maxim of phronesis, which may be understood as fostering "practical, intellectual activity aimed at clarifying 
the problems, risks, and possibilities we face as humans and societies" (Flyvbjerg, 2001: 4). This approach, although still immersed in the scientific tradition, stands opposed to the other domain of Aristotelian reason of episteme that proclaims the a priori nature of "scientific knowledge" (Flyvbjerg, 2001: 2). This brand of research, while disavowed by Peterson, presents a foray into the lives and experiences of marginalized groups that would otherwise be silenced.

In their article, "Transgender Population Size in the United States: A Meta-Regression of Population-Based Probability Samples" for example, Esther L. Meerwijk and Jay M. Sevelius demonstrate just how restrictive and inefficient the gender binary can be for so many people in the U.S. In their study, Meerwijk and Sevelius report that approximately 1.2 million people do not identify with their "sex assigned at birth" (Meerwijk and Sevelius, 2017: 1), adding that this estimate would rise by "1.5 times" if it were to also include other forms of gender nonconformity (Meerwijk and Sevelius, 2017: 1).

Divan et al. confirm this position, arguing in their study that the "recognition as human beings" of trans* and genderqueer folk requires "a guarantee of (...) core rights that recognize [the] legal personhood" of these individuals (Divan et al., 2016: 81). Still, to Divan et al., the acknowledgement of someone's gender identity is just the first step. As they explain, "preventing human rights violations and social exclusion is key to [a] sustainable and equitable development" (Divan et al., 2016, 82) that can only be established with "systemic strategies to reduce the violence against trans people” occurring, necessarily, “at multiple levels" (Divan et al., 2016: 81).

The harmful consequences of the stigmatization faced by trans* people are further discussed in a study published in the Archives of Neuropsychiatry of Istanbul in March of 2017. This study, which included 99 transmen and 42 transwomen participants, reported that the "overall incidence of at least one suicide attempt among participants was 29.8\%" and that of those that did attempt to commit suicide, 76.7\% were under the age of 21 (Şahika Yüksel, et al., 2017: 29). Furthermore, its authors suggest that as youth begin to familiarize themselves with their own identity, "heterosexist false information, which normalizes binary gender" can lead to the "internalization of transphobia, self-blame, shame, and problems that can continue into adult life" (Şahika Yüksel, et al., 2017: 30). Still, suicide is just one possible mode of harm that trans* people may regularly experience. This disavowal of gender identities and sexualities, and the continual denial of adequate health care, social care, and housing diminish any opportunity to generate a more accepting and open environment free of stigmatization and discrimination. The standardization of a limited gender binary that recognizes only two, stable gender categories based on physical sex at birth combined with the persistent refusal to acknowledge identities that defy this system seems, therefore, to cause much greater harm than do the so-called "neo-Marxists" Peterson is so deeply concerned about. 
Despite the growing body of scientific literature that supports and recognizes more fluid definitions of sex and gender while acknowledging the harmful effects of the oppression faced by trans* and genderqueer individuals, Jordan Peterson continues to argue that attempts made to redefine and recognize a wider range of gender expressions and identities is a simple "construction of people who have a political ideology" (Peterson, 2016d). For Peterson then, there is simply no way to make sense of trans* and/or genderqueer individuals within the realm of Western scientific discourse and, therefore, any gender identity that does not conform to his "objective" and "scientific" definition of gender as fixed binary system related to biological sex must be invalid and therefore repudiated. Peterson's erasure through disavowal of trans* peoples' chosen preferred pronouns consequently locates cisgender identities within the realm of 'reality,' and any other nonnormative gender identities within the realm of artificiality.

\section{Baudrillard, Reality, and Truth}

Peterson's categorization of people based on their connection to a "real" biological imperative or ideologically motivated political strategy implies that there is an essential reality pertaining to gender identity that exists across cultural epistemes and historical epochs. ${ }^{2}$ Though Peterson suggests that there is a fundamental "Truth" pertaining to identity, and that this "Truth" can be rigorously supported with the use of scientific methods, his claims do not account for the possibility that the gender binary is itself an ideologically motivated tool, and that there may in fact be no ultimate "Truth" pertaining to gender identity. Jean Baudrillard has vigorously challenged the position held by scholars such as Peterson on objectivity and "Truth," suggesting instead that "science, like any discourse, is organized on the basis of a conventional logic" adding that it "explains things which have been defined and formulized in advance and which subsequently conform to these explanations" (Baudrillard, 1993b: 61). The studies presented above, remaining faithful to the Aristotelian notion of phronesis, resonate in concert with Baudrillard's theorization of science because they do not refuse that science is valid and results may be concluded from them, but that these conclusions should not be transposed onto any societal or cultural context. Therefore, despite the many attempts to dissuade a Baudrillardian praxis for scientific conduct, these studies speak to the late Baudrillard's conception of singularity which holds that "every detail of the world is perfect if it is not referred to some larger set" (Baudrillard, 2005: 140). This turn to Baudrillard then may appear ironic given the implicit rejection of postmodernism by Peterson and many other members of the

\footnotetext{
2 Of course, not all trans* people locate themselves outside of the gender binary. Those people reserve every right to identify how they choose, even if it subscribes the dominant notion of the gender binary. The goal of this argument is not to condemn, in any way, trans* people who fit within the gender binary, but to suggest that the gender binary is but one of a plethora of ways to look at gender identity and expression.
} 
scientific community. However, this paper sketches a version of Baudrillardian theory that speaks to the Aristotelian notion of phronesis to broaden the conceptual and physical possibility of scientific research. Prior to exploring Baudrillard, it is important to consider the way that contemporary psychological research has become attuned to the nature of simulation in understanding humans and their relationships to the world.

Lisa Feldman Barrett, professor of psychology at Northeastern University, has greatly challenged what she calls the "classical view of emotion" that maintains there to be universal attributes to human emotion and interaction. In her How Emotions are Made: The Secret Life of the Brain, she disturbs this classical view by suggesting that the world is understood by humans through "simulations," which dictates what we "see, hear, touch, taste and smell" (Barrett, 2017: 27). Moreover, these simulations can "cause tangible changes in your body" (Barrett, 2017: 28). While Barrett does not draw a direct parallel between her own work and that of Baudrillard, there are many parallels between their conceptions of simulation. This is because, like Baudrillard, Barrett is trying to wrest the broader scientific community from the clutches of transcendental, universalistic assumptions regarding emotion and the human body. Barrett proposes that we become attuned to our relationship to simulation opposed to these transcendent principles because "people spend at least half their waking hours simulating rather than paying attention to the world around them, and this pure simulation strongly drives their feelings" (Barrett, 2017: 71).

Reality, for Baudrillard, is always caught in a play of signification, and suggestions of a "naturality" made by the authoritative scientific community mistake the only true nature of the world as a world of appearances in which there may not be "anything but a discourse of the real and the rational" (Baudrillard, 2008b: 14). According to Baudrillard then, notions of an objective "Truth" are fundamentally flawed and any attempt to occupy an objective field of study is bound to fail and merely become "signs: signifiers of a 'real' signified" (Baudrillard, 1973: 48). The fundamental impossibility of performing "objective" studies and/or of revealing fundamental truths is understood by Baudrillard and his theory of simulation. For Baudrillard, simulation occurs when "the world has become real beyond our wildest expectations" (Baudrillard, 2008b: 65) and can be described as the outcome of a calculated move to put the "illusion of the world to death" (Baudrillard, 2008b: 17). Scientific discourses that rely on notions of objectivity and "Truth" therefore dissolve "into the imaginary of the sign, or the sphere of truth" (Baudrillard, 2008b: 17) and leave us with reality (and therefore simulation) in all its glory. The 'real' then, is "merely a particular case of that simulation" (2008b: 17) that Baudrillard argues "allows our society to think itself and live itself as superior to all others" (Baudrillard, 1973: 113). Jordan Peterson's 
understanding of the world as fixed, stable, and decipherable through the use of science therefore operates to uphold and reinforce the realm of oppressive simulation.

For Baudrillard, the only adequate way to challenge Peterson's oppressive rhetoric within this realm of simulation is to engage with "seduction," a concept he defines as the "symbolic mastery of forms" (Baudrillard, 2003: 24). Rather than attempt to understand the world as existing outside of appearances, representation, or ideology, seduction diverts things from "their identity, their reality, to destine them for the play of appearances, for their symbolic exchange" (Baudrillard, 2003: 21). Baudrillard's “seduction" opposes Peterson's scientific discourse precisely because seduction is able to engage with the world at the level of appearances. This approach remains faithful to his concept of singularity as it takes cultural formations, in the demonstration of rites and rituals, as immanent in any culturally faithful analysis in the form of science or otherwise. This line of argumentation may be observed in Baudrillard's earlier work when he argues that "only a critique of the political economy of the sign can analyze how the present mode of domination is able to regain, integrate and simultaneously take advantage of [...] all previous,' archaic' modes of production and exchange, infra- or trans- economic (Baudrillard, 1981: 120). Baudrillard's work can then be read as not necessarily opposing the domain of scientific inquiry, but accounting for the degree to which any scientific inquiry should be attuned to the cultural and significator conditions of the object of study.

This critique of the political economy of the sign functions to simultaneously address the nature of signification, while simultaneously challenging the historical and cultural instantiations that have culminated in its potentially oppressive existence. Without this sort of criticism, we run the risk of perpetuating the notion of a "real" method or approach to criticism that mobilizes the discursive and scientific tools of Eurocentric enlightenment thinking that has been so categorically responsible for much of the hegemonic oppression that we find ourselves associated with today. It is in this capacity that Baudrillard is particularly effective at putting forth a methodological imperative for the realization of the Aristotelian notion of phronesis because he refuses to suggest that there is a single way to conduct research, but that research and science may adapt to accommodate the given societal or cultural moment.

\section{Baudrillard, Butler, and those Voices of the Marginalized}

The trans* community is one example of a community that challenges the greater system at hand through a radical re-evaluation of the hyper-normalized position of cisgender people. Riley J. Dennis, a trans* contributor to the internet site Everyday Feminism, disturbs the strict relationship between gender and sex when she argues that "sex is not a biological fact because it is determined by things that are largely changeable" (Dennis, 2017). Still, this is not to say that trans*identity is inherently opposed to any biological 'fact.' As Riki Lane explains, if we simply dismiss “'biologism,' 
we forget that there really is biology that we have to theorize through investigating what is natural, biological, social, and cultural and how these categories develop and condition one another in discourse" (Lane, 2009: 138). Rather, biology should be subjected to the same discursive challenge as is mobilized against the dichotomization of gender.

This radical challenge to the scientific validity of the dichotomization of biological sex presents a Baudrillardian "reversal." This reversal occurs when biological sex is inverted to mirror the highly unsteady terrain of gender identity. No longer is gender something that is predicated on the objective finality of 'sex,' but it is 'sex' that is reversed to be predicated on the fundamental uncertainty of gender identity. In this instance, sex is seduced away from the objective finality of its biological imperative, toward the "form which tends always to unsettle someone in their identity and the meaning they can have for themselves" (Baudrillard, 2003: 22).

Judith Butler adds to this theory, arguing that gender "ought not to be construed as a stable identity or locus of agency from which various acts follow; rather, gender is an identity tenuously constituted in time, instituted in an exterior space through a stylized repetition of acts" (Butler, 2002: 179). By challenging Peterson's understanding of the male/female binary as inextricably linked to a transcendental natural apparatus, Butler confirms Baudrillard's theory of simulation, outlining the play of appearances and signification emblematic of simulation and of gender. As she explains, the "replication of heterosexual constructs in non-heterosexual frames brings into relief the utterly constructed status of the so-called heterosexual original. Thus, gay is to straight not as copy is to original, but, rather, as copy is to copy" (Butler, 2002: 41).

As both Baudrillard and Butler demonstrate, to acknowledge the fluidity, diversity, and multiplicity of gender as a social construct allows us to move closer to the reality of the world, not further away from it. Assumptions about gender as belonging to fixed binary system, however, illustrate our denial of the world as illusion and, therefore, further remove us from our world. Perhaps Baudrillard says it best when he writes that

at all events, illusion is indestructible. The world as it is - which is not at all the 'real' world -perpetually eludes the investigation of meaning, thus causing the present catastrophe of the apparatus of production of the 'real' world, so true is it that illusion cannot be combatted with truth-that is merely to redouble the illusion-but only be a higher illusion (Baudrillard, 2008b: 19).

Jordan Peterson is characteristically emblematic of a drive to purge the world of all illusion. His reliance on scientific rationale, and a very specific scientific rationale at that, attaches meaning to a world that is first and foremost unnatural. For Peterson, there is a "Truth" beneath the illusion. With enough science, reason and rationality, this "Truth" may be attained from under the heavy 
weight of illusion that clouds our judgment and intellect. Peterson's failure to ask if the only truth of the world is that beneath the bedrock of illusion there is only a greater illusion feeds the progression of Western archaeological excavation into illusion and drives this machine of modernity deeper into the bedrock of illusion than ever before. What will remain then, once the final illusion has been purged?

\section{Conclusion}

This paper has attempted to present many of the philosophical and psychological shortcomings of Jordan Peterson's work. By drawing upon a plethora of sources from academic circles indicative of the "hard" and "soft" sciences to the philosophical tradition of the humanities to voices of those marginalized outside of academia, this paper has demonstrated the range of perspectives that oppose and resist many of the facile claims put forth by Peterson. Beyond locating the various contradictions and fallacious remarks Peterson makes, this paper has also argued that Peterson's assault against Bill C-16 risks mirroring the same systemic instantiations of totalitarianism that he claims to know so much about. To re-iterate, this is not to suggest that he represents these movements directly, but that there are many affinities between these oppressive ideological systems and Peterson's faith in a universal conception of truth. This paper serves the purpose of mounting a philosophically analytic rebuttal to Peterson's central claims by performing an immanent critique, pointing to the many shortcomings of his speculations, and locating epistemic fallacies that may be observed in his ideas. This is a necessary form of critique because, unlike the Hegelian mode of oppositional politics that poses a critique from an antithetical and exterior positionality, this form identifies the core of the theoretical inadequacy of Peterson's project from the inside.

\section{References}

Alesworth, Gary (2015): 'Postmodernism', Stanford Encyclopedia of Philosophy. Accessible at https://plato.stanford.edu/entries/postmodernism/ (16 June 2017)

Arendt, Hannah (1994): The Origins of Totalitarianism. $2^{\text {nd }}$ edition. New York: Harcourt, Inc.

Barrett, Lisa Feldman (2017): How Emotions are Made: The Secret Life of the Brain. New York: Mariner Books.

Baudrillard, Jean (1973): The Mirror of Production. Trans. M. Poster. St. Louis: Telos Press.

Baudrillard, Jean (1981): For a Critique of the Political Economy of the Sign. Trans. Charles Levin. London: Telos Press. 
Baudrillard, Jean (1993a): “A Virtual State of Rupture”, in Mike Gane (ed.) Baudrillard Live. New York: Routledge.

Baudrillard, Jean (1993b): Symbolic Exchange \& Death. Trans. I. Hamilton Grant. London: Sage Publications Inc.

Baudrillard, Jean (2003): Passwords. Trans. C. Turner. New York: Verso.

Baudrillard, Jean (2005): The Intelligence of Evil: Or The Lucidity Pact. Transl. C. Turner. London: Bloomsbury.

Baudrillard, Jean (2008a): Fatal Strategies. Trans. P. Beitchman and W.G. J Niesluchowski. Los Angeles: Semiotext(e).

Baudrillard, Jean (2008b): The Perfect Crime. Trans. C. Turner. New York: Verso.

Butler, Judith (2002): Gender Trouble. New York: Routledge.

Canada (2016): 'Bill C-16: First Reading', Parliament of Canada. Accessible at http://www.parl.ca/DocumentViewer/en/42-1/bill/C-16/first-reading (17 May 2016).

Dennis, Riley J. (2017) 'No, Trans Women Are NOT "Biologically Male”. Everyday Feminism. Accessible at: https://everydayfeminism.com/2017/02/trans-women-not-biologically-male/ (10 February 2017).

Divan, Vivek, et al. (2016): 'Transgender social inclusion and equality: a pivotal path to development', Journal of The International AIDS Society 19(2): pp. 79-84. DOI: https://doi.org/10.7448/ias.19.3.20803

Donnan, Mary Ellen (2016): The Shattered Mosaic: How Canadian Social Structures Cause Homelessness. Vernon: JCharlton Publishing Ltd

Flyvbjerg, Bent (2001): Making Social Science Matter: Why Social Inquiry Fails and How it can Succeed Again. Cambridge: Cambridge University Press.

Hemmings, Clare (2011): Why Stories Matter: A Political Grammar of Feminist Theory. London: Duke University Press.

Lane, Riki (2009): 'Trans as Bodily Becoming: Rethinking the Biological as Diversity, Not Dichotomy', Hypatia 24(3): pp. 136-157. DOI: https://doi.org/10.1111/j.1527-2001.2009.01049.x

Meerwijk, Esther L. and Jay M. Sevelius (2017): 'Transgender Population Size in the United States: a Meta-Regression of Population-Based Probability Samples'. American Journal of Public Health 107(2): pp. 1-8. DOI: https://doi.org/10.2105/AJPH.2016.303578 
Meštrović, Stjepan (1993): The Barbarian Temperament: Toward a Postmodern Critical Theory. New York: Routledge.

Nietzsche, Friedrich (2007): The Birth of Tragedy. 9 ed. Trans. R. Spiers. United Kingdom: Cambridge University Press.

Nietzsche, Friedrich (2017): On the Genealogy of Morality. 3 ed. Trans. K. Ansell-Pearson. Ed. Carol Diethe. United Kingdom: Cambridge University Press.

Ontario Human Rights Commission (N.D.) "About the Commission." http://www.ohrc.on.ca/en/about-commission.

Oxford English Dictionary, 'Nihilism',. Accessible at https://en.oxforddictionaries.com/definition/nihilism (15 June, 2017).

Peterson, Jordan (1999): Maps of Meaning: The Architecture of Belief. New York: Routledge.

Peterson, Jordan (2016a): 'Prof Jordan Peterson speaks at University of Toronto protest', YouTube: 8:37. Posted by genuinewitty. Accessible at https://www.youtube.com/watch?v=HAlPjMiaKdw.

Peterson, Jordan (2016b): 'Professor Jordan Peterson Swarmed by Narcissistic SJW Ideologues after UofT Rally', YouTube: 13:20. Posted by Katrina Flemming. https://www.youtube.com/watch?v=O-nvNAcvUPE\&t=1s

Peterson, Jordan (2016c): "Prof. Jordan Peterson: "Absurd" that biological sex and "gender identity" are independent”, YouTube: 2:20. Posted by Rebel Media. Accessible at https://www.youtube.com/watch?v=2dbkJv6566c.

Peterson, Jordan (2016d): 'Genders, Rights and Freedom of Speech', YouTube: 54:58. Posted by The Agenda with Steve Paikan. Accessible at https://www.youtube.com/watch?v=kasiov0ytEc.

Peterson, Jordan (2017a): 'Jordan Peterson: Why You Have To Fight Postmodernism', YouTube: 12:00. Posted by philosophyinsights. Accessible at https://www.youtube.com/watch?v=MPojltjv4M0

Peterson, Jordan (2017b): 'Jordan Peterson - Foucault The Reprehensible \& Derrida The Trickster,' YouTube: 10:56. Posted by Bite-Sized Philosophy. Accessible at https: / www.youtube.com/watch?v=NBFSDd 5tiE\&t $=50 \mathrm{~s}$.

Peterson, Jordan (2017c): 'Dr. Jordan Peterson on Western Civilization - every "snowflake" should hear this!', YouTube: 2:35. Posted by Ocean of Freedom Accessible at https://www.youtube.com/watch?v= ${ }_{\mathrm{OXy}} 17 \mathrm{y} 2 \mathrm{~Gb} 4 \mathrm{M}$. Consulted July 1st, 2017. 
Peterson, Jordan (2017d): 'Jordan Peterson Exposes the Postmodernist Agenda (Part 1 of 7)', YouTube: 6:31. Posted by Epoch Times. Accessible at https://www.youtube.com/watch?v=PkNzYttjSHE

Peterson, Jordan (2017e): 'Jordan Peterson on Becoming an Independent Person', You'Tube: 6:33. Posted by Personality Owl. Accessible at https://www.youtube.com/watch?v=DbRu-XnK5RU

Peterson, Jordan (2017f): 'Nietzsche and Christianity', YouTube: 6:49. Posted by Dose of Truth. Accessible athttps://www.youtube.com/watch?v=KgBuOQL1VYY

Peterson, Jordan (2017g): 'Jordan Peterson - Banned at Linfield - JP starts at 6:05', YouTube: 1:52:32. Posted by Joe Tyndall. Accessible at https://www.youtube.com/watch?v=X3gztiMdsGA

Peterson, Jordan (2017h): Jordan Peterson, "Jordan Peterson: Political Correctness | Islam | Marxism," YouTube, 14:58, posted by Democracy in Name Only, April 24, 2017. https://www.youtube.com/watch?v=xinUdW7iZ78. Consulted July 1 $1^{\text {st }}, 2017$.

Peterson, Jordan (2017i): 'Jordan Peterson on Milo, Free Speech \& Postmodernism', YouTube: 18:13. Posted by Rebel Media. Accessible at https://www.youtube.com/watch?v=sv17a0uIX2Y

Wolff, Richard D. and Stephen Cullenberg (1986): 'Marxism and Post-Marxism', Social Text (15): pp. 126-135. DOI: https://doi.org/10.2307/466496

Yüksel, Şahika, et al. (2017): 'A Clinically Neglected Topic: Risk of Suicide in Transgender Individuals', Archives of Neuropsychiatry / Noropsikiatri Arsivi 54(1): pp. 28-32. DOI: https://doi.org/10.5152/npa.2016.10075 